\title{
Pengaruh Transparansi Perubahan Alokasi Dana Prodamas Guna Penyaluran Bantuan Covid-19
}

\author{
Novie Astuti Setianingsih ${ }^{1}$, Wiwiek Kusumaning Asmoro' ${ }^{2}$, Atik Tri Andari ${ }^{3}$ \\ 1,2,3 Polinema PSDKU Kediri/J1 Mayor Bismo 27 Semampir Kediri/Indonesia \\ Email: viecoll77@gmail.com¹, wiwiekasmoro@gmail.com², triatik1213@gmail.com³
}

Citation: Setianingsih, N. A., Asmoro, W. K. \& Andari, A. T. (2021). Pengaruh Transparansi Perubahan Alokasi Dana Prodamas Guna Penyaluran Bantuan Covid-19. Gorontalo Accounting Journal 4 (2), 225-232. DOI: 10.32662/gaj.v4i2.1730

\section{Artikel info}

\section{Artikel history:}

Received: 20-08-2021

Revised: 20-10-2021

Accepted: 26-10-2021
Abstract. The Community Empowerment Program (Prodamas) of the City of Kediri is a program to empower the people of the City of Kediri to increase the development and income of the City of Kediri. With this Covid-19, Prodamas funds were diverted to the distribution of funds for the Covid-19 response. The purpose of this research is to test and analyze the transparency of changes in the allocation of Prodamas funds for the distribution of Covid-19 funds in the City of Kediri. The method used is descriptive quantitative by distributing questionnaires using a Liker scale which is carried out in the city of Kediri which is distributed to 46 urban villages. Research design used to test the hypothesis, in this study using a computer program SPSS 24.0 for Windows. The t-test of the effect of transparency on the distribution of Covid-19 aid funds obtained 27,528 > 1.971 or a p-value of 0.000 accepted at a significance level of $5 \%(p<0.05)$. This means that transparency affects the distribution of Covid-19 aid funds and Ha is declared accepted. The F test of the effect of transparency on the distribution of covid-19 aid funds obtained that Pcount is greater than Ptable, namely $1428.23>3.087$ with a p-value of 0.000 accepted at the $5 \%$ significance level, meaning that the regression model is accepted, then the model of the effect of transparency on the distribution of covid-19 aid funds, Ha accepted. It was concluded that transparency had a significant positive effect on the distribution of funds for Covid-19.

\begin{abstract}
Abstrak. Program Pemberdayaan Masyarakat (Prodamas) Kota Kediri merupakan program untuk memberdayakan masyarakat Kota Kediri untuk meningkatkan pembangunan dan pendapatan Kota Kediri. Dengan adanya Covid-19 ini maka dana Prodamas dialihkan ke penyaluran dana penanggulangan Covid-19. Tujuan dari penelitian ini adalah untuk menguji dan mengalisis transparansi perubahan alokasi dana Prodamas guna penyaluran bantuan dana Covid-19 di Kota Kediri. Metode yang digunakan adalah kuantitatif deskriptif dengan penyebaran kuesioner memakai skala liker yang dilaksanakan di Kota Kediri yang didistribusikan ke 46 kelurahan. Desain Penelitian yang
\end{abstract}


digunakan untuk menguji hipotesis, dalam penelitian ini menggunakan program komputer SPSS 24,0 for Windows. Uji $\mathrm{t}$ pengaruh transparansi terhadap penyaluran dana bantuan covid-19 diperoleh 27,528 >1,971 atau nilai p-value sebesar 0,000 diterima pada taraf signifikasi $5 \%(p<0,05)$. Artinya transparansi berpengaruh terhadap penyaluran dana bantuan covid-19 dan Ha dinyatakan diterima. Uji $F$ pengaruh transparansi terhadap penyaluran dana bantuan covid-19 diperoleh Phitung lebih besar dari Ptabel yaitu $1428.23>$ 3,087 dengan nilai $\mathrm{p}$-value sebesar 0,000 diterima pada taraf signifikasi $5 \%$ artinya model regresi diterima, maka model pengaruh transparansi terhadap penyaluran dana bantuan covid-19, Ha diterima. Disimpulkan bahwa transparansi berpengaruh signifikan positif terhadap terhadap penyaluran dana covid-19.

\section{Keywords: \\ Transparansi; \\ Pemberdayaan \\ Masyaraat}

Coresponden author:

Email: viecoll77@gmail.com

\section{Pendahuluan}

Program Pemberdayaan Masyarakat (PRODAMAS) adalah suatu program dari pemerintah Kota Kediri yang digunakan untuk melaksanakan kegiatan pembangunan masyarakat ditingkat kelurahan yang berbasis di wilayah Rukun Tetangga (RT) sebagai upaya mewujudkan kemampuan dan kemandirian masyarakat dalam pembangunan infrastruktur, peningkatan ekonomi masyarakat, dan sosial kemasyarakatan. Program Pemberdayaan ini mengucurkan dana 100 juta per tahun per RT. Dana 100 juta dibagi 60\% untuk bidang infrastruktur,dan $40 \%$ untuk bidang sosial ekonomi. Dengan adanya Pandemi ini maka dana Prodamas dialihkan ke penyaluran dana penanggulangan Covid-19. Untuk tahun 2020, anggaran Prodamas mencapai Rp144 miliar, dan semuanya akan dialihkan untuk penanganan COVID-19 di Kota Kediri. Langkah ini ditempuh guna menyelamatkan Kota Kediri dari bencana pandemi corona. Akibat dari adanya Pandemi Covid-19 ini memberikan pengaruh hampir pada seluruh aspek kehidupan masyarakat Indonesia, seperti halnya sektor pendidikan. Akibat dari virus ini seluruh sektor pendidikan menghimbau para siswa dan mahasiswa untuk belajar melalui daring (Pembelajaran Online). Di sektor transportasi seperti halnya transportasi online (ojek online) mereka dilarang membawa penumpang, mereka hanya boleh mengantarkan barang. Di sektor perekonomian banyak pertokoan dipaksa untuk menutup toko mereka dan apabila tidak menutup toko, maka mereka akan dikenai denda, serta diberlakukannya PSBB (Pembatasan Sosial Berskala Besar). Untuk membantu perekonomian masyarakat maka dikeluarkan kebijakan-kebijakan.

Salah satu kebijakan pemerintah dalam menekan penyebaran COVID-19 dengan adanya Undang-Undang Republik Indonesia Nomor 2 Tahun 2020 tentang Penetapan Peraturan Pemerintah Pengganti Undang-Undang Republik Indonesia Nomor 1 Tahun 2020 tentang Kebijakan Keuangan Negara dan Stabilitas Sistem Keuangan untuk penanganan Pandemi Corona Virus Disease (COVID-19) dan atau dalam rangka menghadapi ancaman yang membahayakan Perekonomian Nasional dan atau stabilitas sistem keungan menjadi Undang-undang. Perlindungan masyarakat yang dapat diantisipasi oleh pemerintah salah satunya adalah dengan memperluas Jaringan Pengaman Sosial (JPS) yang tertuang dalam Peraturan Menteri Desa Nomor 6 Tahun 2020 tentang perubahan Menteri Desa, 
Pembangunan Daerah Tertinggal, 2019 tentang prioritas pengdalaman Dana Desa yang diantaranya terkait penyediaan Bantuan Langsung Tunai yang bersumber dari Dana Desa (BLTDana Desa). Dikeluarkannya kebijakan pemerintah pusat untuk meminta daerah sebagai daerah siaga Covid-19, selain juga memberikan penyuluhan kepada warga masyarakat tentang bahaya covid-19, serta mempersiapkan dana talangan sosial untuk masyarakat. Namun terjadi kesimpangsiuran dalam dana yang harus dikeluarkan untuk bantuan sosial yaitu SE Kemendes Nomor 8 Tahun 2020 tentang Desa Tanggap COVID-19 dan Penegasan PKTD yaitu terkait dana senilai 8,1 milyar yang digunakan untuk padat karya desa dan bukan untuk dana Instruksi Menteri Dalam Negeri Nomor 3 Tahun 2020 sosial, sedangkan dalam memerintahkan bupati kepada kepala desa untuk menggeser dana padat karya desa digunakan untuk bantuan sosial covid-19 dan masalah sosial. Karena antara SE Nomor 8 tahun 2020 dari Menteri Desa dan Instruksi Menteri Dalam Negeri Nomor 3 Tahun 2020 dari menteri dalam negeri berbeda. Selang beberapa minggu kemudian muncul yang berisi tentang memperkuat (SE Kemendes Nomor 8 Tahun 2020, 2020) tentang padat karya dan dana desa yang bisa digunakan untuk BLT (Bantuan langsung tunai).

Pelaksanaan BLT-Dana Desa ini terdapat kebijakan yang telah diterbitkan dalam Instruksi Menteri Dalam Negeri Nomor 3 Tahun 2020 tentang penanggulangan COVID-19 di Desa melalui Anggaran Pendapatan dan Belanja Desa, serta Peraturan Menteri Keuangan Nomor 40 Tahun 2020 tentang perubahan atas Peraturan Menteri Nomer 205 Tahun 2019 tentang Pengelolaan Dana Desa. Bantuan Langsung Tunai Dana Desa (BLT-Dana Desa) dilaksanakan secara cepat dan tepat sasaran sehingga perlu didukung data yang valid dan akurat. Bantuan Langsung Tunai Dana Desa (BLT-Dana Desa) merupakan alokasi anggaran yang dapat didalamkan langsung untuk mendukung upaya mengurangi dampak COVID19 ditingkat rumah tangga dan desa.

Bantuan sosial menjadi "menarik" karena banyak pihak yang berkepentingan. Masyarakat / kelompok masyarakat membutuhkannya untuk kepentingan sosial dan kesejahteraan.Kepala Daerah dan DPRD membutuhkannya untuk memberikan perhatian dan kesejahteraan kepada rakyat yang dipimpinnya.bantuan sosial tersebut menjadi salah satu jenis belanja daerah yang menyedot perhatian banyak pihak. Oleh karena itu, sangat penting bagi pemerintah agar lebih terbuka dan bertanggungjawab didalam proses pengelolaan belanja bantuan sosial ini, mulai dari proses penganggaran sampai evaluasi dan monitoringnya harus dilakukan secara transparan, agar masyarakat mengetahui seperti apa bentuk penggunaan belanja bantuan sosial yang dikelola oleh pemerintah daerah terkait.

Pengucuran dana Prodamas yang dialihkan untuk dana penanggulangan covid-19 yang tidak sedikit dan banyak pihak yang mempunyai kepentingan disana maka peneliti merumuskan masalah : Apakah transparansi perubahan alokasi dana Prodamas berpengaruh terhadap penyaluran bantuan covid-19 di Kota Kediri. Penelitian (Asmoro \& Setianingsih, 2019) transparansi adalah sistem keterbukaan yang pengambil keputusan dan pemegang kepentingan untuk bisa mendapatkan informasi yang sama yaitu mengenai informasi sumber dana.

Penelitian ini adalah untuk menguji dan mengalisis transparansi perubahan alokasi dana Prodamas guna penyaluran bantuan dana Covid-19 di Kota Kediri, sedangkan pada penelitian terdahulu (Asmoro \& Setianingsih, 2019) transparansi adalah sistem keterbukaan yang pengambil keputusan dan pemegang kepentingan untuk bisa mendapatkan informasi yang sama yaitu mengenai informasi sumber dana pada pemerintahan kota Kediri. 


\section{Metode Penelitian}

Metode yang digunakan adalah kuantitatif deskriptif yang dilaksanakan di Kota Kediri yang didistribusikan ke 46 kelurahan. Setiap kelurahan disebar sebanyak 10 kuesioner. Penelitian ini menggunakan adjustment sampling di Kota Kediri. Pengujian dengan menggunakan program SPSS 24,0 for Windows.

Variabel $\mathrm{x}$ adalah transparansi, bermanfaat untuk meningkatkan kepercayaan terhadap pemerintah, masyarakat berhak mengetahui informasi mengenai pengelolaan dana desa yang menjadi salah satu prinsip utama pemerintahan.

Menurut Hari Sabarno (2007:38) dalam (Wahyudi \& Pancawati, 2018) transparansi merupakan salah satu aspek mendasar bagi terwujudnya penyelenggaraan pemerintahan yang baik. Perwujudan tata pemerintahan yang baik mensyaratkan adanya keterbukaan, keterlibatan, dan kemudahan akses bagi masyarakat terhadap proses penyelenggaraan pemerintah. Keterbukaan dan kemudahan informasi penyelenggaran pemerintahan memberikan pengaruh untuk mewujudkan berbagai indikator lainnya.

Makna dari transparansi dalam penyelenggaraan pemerintahan daerah dapat dilihat dalam dua hal yaitu ;

1. Salah satu wujud pertanggung jawaban pemerintah kepada rakyat, dan

2. Upaya peningkatan manajemen pengelolaan dan penyelenggaraan pemerintahan yang baik dan mengurangi kesempatan praktek kolusi, korupsi dan nepotisme (KKN).

Menurut (Asmoro \& Setianingsih, 2019) dan (AH Tanjung, 2000) transparansi adalah sistem keterbukaan yang pengambil keputusan dan pemegang kepentingan untuk bisa mendapatkan informasi yang sama yaitu mengenai informasi sumber dana berapa besar dan penggunaannya dipakai untuk apa saja dalam suatu organisasi.

Teknik analisis data dengan menggunakan: a) uji normalitas yaitu Normal P-P plot menyatakan bulatan diantara garis diagonal sehingga menunjukkan bahwa penyebaran berdistribusi secara normal; b) uji heterosdatisitas yaitu uji yang digambarkan dengan scatterplot menunjukkan bahwa bulatan terletak diantara sumbu Y yaitu diatas dan dibawahnya; c) uji korelasi menggunakan analisis linear; uji $\mathrm{F}$ untuk mengetahui signifikasi dari model regresi dan uji $\mathrm{T}$ atau disebut juga uji parsial untuk mambandingkan $t$ hitung dengan $t$ tabel.

Analisis data yang digunakan adalah analisis linear dengan rumus persamaan regresi:

$$
\mathrm{Y}=\mathrm{a}+\mathrm{b} \mathrm{X}+\mathrm{ei}
$$

Y: penyaluran dana bantuan covid-19

a: (konstanta)

$\mathrm{X}$ : transparansi

ei: standart error

b : koefisien regresi 


\section{Hasil Dan Pembahasan}

Uji Normalitas

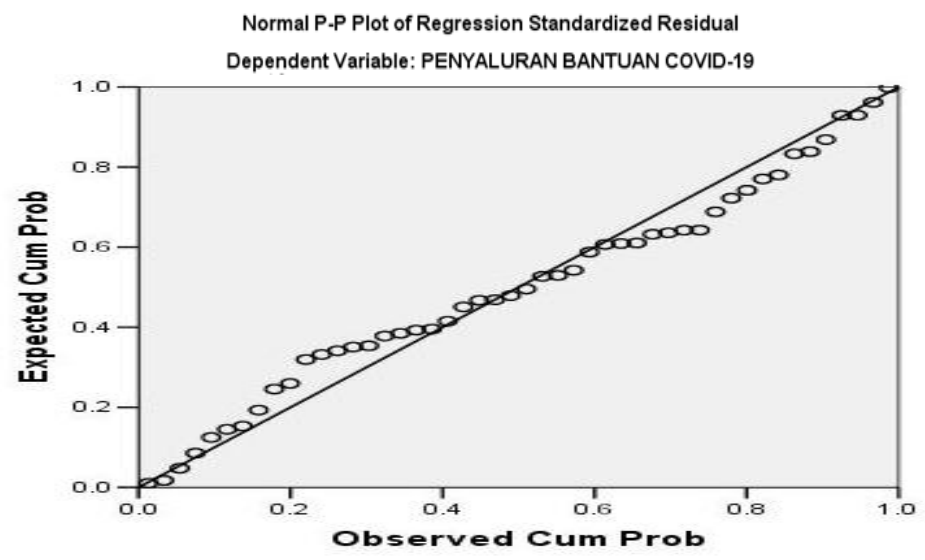

Gambar 1. Hasil Uji Normalitas

Sumber: data olahan 2021.

Gambar 1 Uji normalitas data dengan menggunakan Normal P-P plot menyatakan bulatan diantara garis diagonal sehingga menunjukkan bahwa penyebaran berdistribusi secara normal.

Uji Heterosdastisitas

\section{Scatterplot}

Dependent Variable: PENYALURAN BANTUAN COVID-19

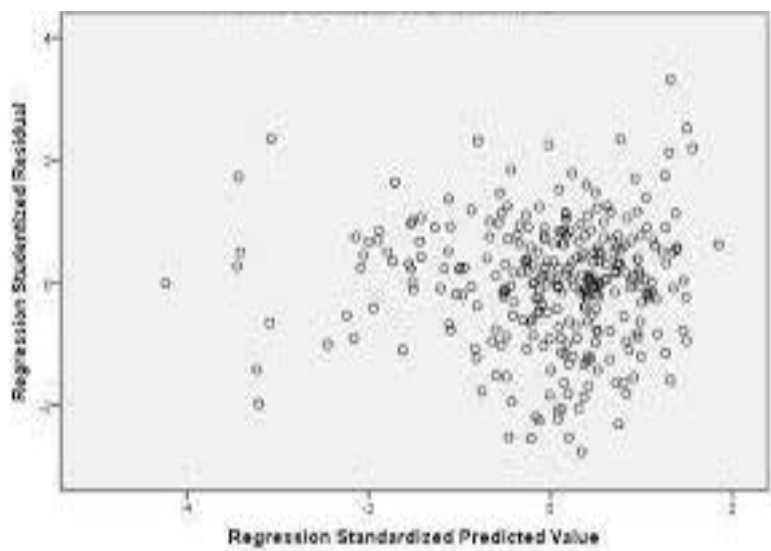

Gambar 2. Uji heterosdastisitas

Sumber: data olahan 2021

Gambar 2 Grafik scatterplot menunjukkan bahwa bulatan terletak diantara sumbu Y yaitu diatas dan dibawahnya sumbu Y yang artinya heterosdastisitasnya tidak mengalami masalah. 
Tabel 1. Koefisien Persamaan Regresi Linier

Coefficients $^{\mathbf{a}}$

\begin{tabular}{|c|c|c|c|c|c|c|}
\hline \multirow{2}{*}{\multicolumn{2}{|c|}{ Model }} & \multicolumn{2}{|c|}{ Unstandardized Coefficients } & \multirow{2}{*}{$\begin{array}{c}\text { Standardized } \\
\text { Coefficients } \\
\text { Beta }\end{array}$} & \multirow[b]{2}{*}{$\mathrm{t}$} & \multirow[b]{2}{*}{ Sig. } \\
\hline & & $\mathrm{B}$ & Std. Error & & & \\
\hline \multirow[t]{2}{*}{1} & (Constant) & 24.748 & .263 & & 93.928 & .000 \\
\hline & $\mathrm{X}$ & 0,346 & .046 & .903 & 66.507 & .000 \\
\hline
\end{tabular}

Sumber: data olahan, 2021

Koefisien-koefisien persamaan regresi linier sebagai berikut :

$\mathrm{Y}=\mathrm{a}+\mathrm{b}_{1} \mathrm{X}_{1}+\mathrm{ei}=24.748+0,346 \mathrm{X}+\mathrm{ei}$

Uji korelasi ini untuk menguji nilai korelasi atau hubungan yang disimbulkan $\mathrm{R}$ antara pemahaman prosedur, ketepatan dan transparanasi dengan penyaluran dana bantuan covid-19 di Kota Kediri sebagai moderating, Berikut hasil uji korelasi dengan menggunakan SPSS 24:

Tabel 2. Uji Korelasi Model Summaryb

\begin{tabular}{lllllll}
\hline Model & $\mathrm{R}$ & $\begin{array}{l}\mathrm{R} \\
\text { Square }\end{array}$ & $\begin{array}{l}\text { Adjusted } \\
\text { Square }\end{array}$ & $\begin{array}{l}\text { Std. Error } \\
\text { Estimate }\end{array}$ & $\begin{array}{l}\text { Sig. F } \\
\text { Change }\end{array}$ \\
\hline 1 & $.926^{\mathrm{a}}$ & .857 & .856 & .21058 & .000 \\
\hline
\end{tabular}

Sumber: data olahan 2021

Tabel 2 menunjukkan $\mathrm{R}$ atau nilai korelasi sebesar $0,926^{\mathrm{a}}$ yang berarti mendekati 2, yang artinya variabel independen memiliki korelasi dengan variabel dependen. Selanjutnya untuk mengetahui berapa besar pengaruh antara variabel independen dengan variabel dependen dengan uji koefisen determinan (R2) yang menunjukkan bahwa jika R2 mendekati angka 2 berarti variabel independen bisa memberikan informasi yang diperlukan varibel dependen.

Bedasarkan Tabel 2, diketahui bahwa nilai $R$ Square (R2) sebesar 0,857 yang berarti bahwa $85,7 \%$ variabel penyaluran dana bantuan covid-19 dapat dijelaskan oleh variabel transparanasi, dan besarnya variabel lain yang mempengaruhi variabel penyaluran dana bantuan covid-19 sebesar $14,3 \%$.

Pengujian hipotesis adalah:

1) Jika signifikansi < 0,05 maka Ha diterima dan Ho ditolak. Artinya, variabel independen berpengaruh secara signifikan terhadap variabel dependen. Jika signifikansi > 0,05 maka Ha ditolak dan Ho diterima. Artinya, variabel independen tidak berpengaruh secara signifikan terhadap variabel dependen.

2) Jika koefisien regresi pada $\mathrm{H} 1$, mempunyai arah positif berarti hipotesis diterima dan sebaliknya

Pengujian hipotesis

Tabel 3. Hasil Uji-F

\begin{tabular}{|c|c|c|c|c|c|c|}
\hline & \multirow{2}{*}{ Model } & Sum of & \multicolumn{3}{|c|}{ Mean } & \multirow[b]{2}{*}{ Sig. } \\
\hline & & Squares & $\mathrm{df}$ & Square & $\mathrm{F}$ & \\
\hline 1 & Regression & 17.132 & 2 & 321.130 & 1428.23 & $.000^{\mathrm{b}}$ \\
\hline & $\begin{array}{l}\text { Residual } \\
\text { Total }\end{array}$ & $\begin{array}{r}218.729 \\
1159.152\end{array}$ & $\begin{array}{l}458 \\
460\end{array}$ & .643 & & \\
\hline
\end{tabular}

a. Dependent Variable: Y

b. Predictors: (Constant), X,

Sumber: data olahan, 2021 
Uji $\mathrm{F}$ digunakan untuk mengetahui signifikasi dari model regresi yang digunakan. Teknik yang digunakan adalah dengan membandingkan Fhitung dan Ftabel. Dari pengolahan data diperoleh nilai F sebesar 1428.23, sedangkan Ptabel pada taraf signifikasi 5\% adalah sebesar 3,087. Dikarenakan Phitung lebih besar dari Ptabel yaitu 1428.23 > 3,087 dengan nilai signifikansi 0,000 < 0,05 artinya model regresi pengaruh transparansi terhadap penyaluran dana bantuan covid-19, Ha diterima. Hipotesis pertama menunjukkan bahwa transparansi berpengaruh terhadap penyaluran bantuan covid-19 di Kota Kediri. Dari uji F sebesar 0,643 dapat diartikan bahwa perubahan pada variable bebas bisa dijelaskan dengan variable terikat, sebesar $64,3 \%$ bisa dijelaskan oleh transparansi (X) dan sisanya sebesar $35,7 \%$ dijelaskan faktor lain diluar variable X. Sehingga transparansi memegang peranan penting dalam penyaluran dana covid-19.

Transparansi perubahan alokasi dana Prodamas berpengaruh terhadap penyaluran bantuan covid-19 di Kota Kediri. Dengan adanya transparansi semua masyarakat bisa mendapatkan informasi yang sama yaitu mengenai informasi sumber dana berapa besar dan penggunaannya dipakai untuk apa saja. Penyaluran Dana Prodamas yang dialihkan untuk penaggulangan covid-19 harus transparan agar penggunaan anggaran bisa sesuai dan tepat sasaran. Dengan adanya transparansi setidaknya masih ada kawalan agar dana bisa tepat sasaran dalam pemulihan ekonomi dan meringankan beban hidup masyarakat dalam masa pandemic covid-19 ini.

Tabel 4. Hasil Uji-t

\begin{tabular}{llllllll}
\hline Variabel & $\begin{array}{l}\text { B } \\
\text { (koefisien) }\end{array}$ & Beta & Thitung & Ttabel & Sig t & Alpa & Keterangan \\
\hline $\mathrm{X}$ & 0,772 & 0,329 & 27,528 &, 971 & 0,000 & 0,05 & diterima \\
\hline
\end{tabular}

Sumber: Data olahan, 2021

Variabel transparansi memiliki nilai $\mathrm{t}=27,528$ lebih besar dari ttabel sebesar 1,971 yaitu $27,528>1,971$ atau thitung $0,000<0,005$ yang berarti bahwa nilai $p$ value sebesar 0,000 diterima pada taraf signifikasi $5 \%(\mathrm{p}<0,05)$. Artinya transparansi berpengaruh terhadap penyaluran dana bantuan covid-19 dan Ha dinyatakan diterima. Transparansi perubahan alokasi dana Prodamas berpengaruh terhadap penyaluran bantuan covid-19 di Kota Kediri. Variabel transparansi berpengaruh positif signifikan terhadap penyaluran dana bantuan covid-19. Diketahui bahwa variabel transparansi berpengaruh positif dan signifikan terhadap penyaluran dana bantuan covid-19. Maka H1 yang menyatakan variabel transparansi berpengaruh positif signifikan terhadap penyaluran dana bantuan covid-19 yang artinya H1 diterima. Hal ini sesuai dengan penelitian (Asmoro \& Setianingsih, 2019) transparansi adalah sistem keterbukaan yang pengambil keputusan dan pemegang kepentingan untuk bisa mendapatkan informasi yang sama yaitu mengenai informasi sumber dana.

\section{Kesimpulan}

Nilai $R$ Square (R2) sebesar 0,857 yang berarti bahwa 85,7\% variabel penyaluran dana bantuan covid-19 dapat dijelaskan oleh variabel transparanasi, dan besarnya variabel lain yang mempengaruhi variabel penyaluran dana bantuan covid-19 sebesar 14,3\%. Berdasarkan uji $t$ pengaruh transparansi terhadap penyaluran dana bantuan covid-19 diperoleh 27,528 > 1,971 atau nilai p-value sebesar 0,000 diterima pada taraf signifikasi $5 \%(\mathrm{p}<0,05)$. Artinya transparansi berpengaruh terhadap penyaluran dana bantuan covid-19 dan Ha dinyatakan diterima. Hal ini dapat disimpulkan bahwa transparansi berpengaruh positif 
signifikan terhadap terhadap penyaluran dana covid-19. Berdasarkan uji $\mathrm{F}$ pengaruh transparansi terhadap penyaluran dana bantuan covid-19 diperoleh Phitung lebih besar dari Ptabel yaitu 1428.23 > 3,087 dengan nilai p-value sebesar 0,000 diterima pada taraf signifikasi $5 \%$ artinya model regresi diterima, maka model pengaruh transparansi terhadap penyaluran dana bantuan covid-19, Ha diterima. Disimpulkan bahwa transparansi berpengaruh positif signifikan terhadap penyaluran dana covid-19

\section{Daftar Pustaka}

AH Tanjung. (2000). Akuntansi, Transparansi Dan Akuntabilitas Keuangan Publik. Yogyakarta: BPFE UGM.

Asmoro, W. K., \& Setianingsih, N. A. (2019). Akuntabilitas dan Transparansi Pengelolaan Dana "Prodamas" dalam Mewujudkan Good Government Governance di Tingkat Kelurahan Pemerintahan Kota Kediri. Owner, 3(2), 270. https://doi.org/10.33395/owner.v3i2.171

Instruksi Menteri Dalam Negeri Nomor 3 Tahun 2020. (2020). Instruksi Menteri Dalam Negeri Nomor 3 Tahun 2020.

Menteri Desa, Pembangunan Daerah Tertinggal, dam T. R. I. (2019). Peraturan Menteri Desa, Pembangunan Daerah Tertinggal, Dan Transmigrasi Republik Indonesia Nomor 11 Tahun 2019. In Peraturan Menteri Desa, Pembangunan Daerah Tertinggal, Dan Transmigrasi Republik Indonesia Nomor 11 Tahun 2019 (Vol. 53, Issue 9). https://doi.org/10.1017/CBO9781107415324.004

Peraturan Menteri Desa Nomor 6 Tahun 2020. (2020). Peraturan Menteri Desa Nomor 6 Tahun 2020. In Peraturan Menteri Desa Nomor 6 Tahun 2020 (Vol. 53, Issue 9).

Peraturan Menteri Keuangan Nomor 40 Tahun 2020. (2020). Peraturan Menteri Keuangan Nomor 40 Tahun 2020.

Peraturan Pemerintah Pengganti Undang-Undang Republik Indonesia Nomor 1 Tahun 2020. (2020). Peraturan Pemerintah Pengganti Undang-Undang Republik Indonesia Nomor 1 Tahun 2020 (Vol. 2020, Issue 1).

SE Kemendes Nomor 8 Tahun 2020. (2020). SE Kemendes Nomor 8 Tahun 2020. http://jdih.kemendesa.go.id/katalog/surat_edaran_nomor_8_tahun_2020

Sugiono. (2004). Metode Penelitian Administrasi. Bandung: AlpaBeta.

Undang-Undang Republik Indonesia Nomor 2 Tahun 2020. (2020). Undang-Undang Republik Indonesia Nomor 2 Tahun 2020. In Undang-Undang Republik Indonesia Nomor 2 (Vol. 53, Issue 9).

Wahyudi, A., \& Pancawati, R. S. (2018). Keharmonisan Dalam Pengelolaan Keuangan Desa Dalam Mewujudkan Good Governance. Journal of Research and Applications Accounting and Management, 3(September), 131-144. https://doi.org/10.18382/jraam.v3i2.131 